\title{
About the Strengthening of Publicity in the Formation of Local Representative Bodies: Rather-Legal Analysis
}

\author{
Tatiana N. Mikheeva ${ }^{1}$, Valentin V. Kudryavtsev ${ }^{1}$ \& Julia S. Yaichnikova ${ }^{1}$ \\ ${ }^{1}$ Mari State University, Yoshkar-Ola, Russia \\ Correspondence: Tatiana N. Mikheeva, Juridicial faculty, Mari State University, Yoshkar-Ola, Republic of Mari \\ El, Lenin square 1, 424001, Yoshkar-Ola, Russia. Tel: 7-961-377-3343. E-mail: tnmiheeva@marsu.ru
}

Received: February 21, 2015

Accepted: March 15, 2015

Online Published: April 29, 2015

doi:10.5539/res.v7n8p280

URL: http://dx.doi.org/10.5539/res.v7n8p280

\begin{abstract}
Laws of historical development of European and North American countries allow us to consider decentralization of the system of public administration as an essential condition to the effective development of society. The formation of local authorities is a prerequisite for the work of government institutions to the benefit of the person. Representative bodies of municipalities are an integral part of the system of those authorities. The article analyzes the main ways of their formation in the United States compared with Russian counterparts. The mission is, following American experience, to identify the optimal model of citizens' participation and their associations in the formation of local representative bodies in the Russian municipalities that would correspond to the principles of publicity and openness. The work challenges to review the practice of the formation of representative bodies by citizens. According to the results of this analysis the authors come up with some proposals to improve the legal regulation of citizens' participation and their associations in the formation of local representative bodies, to establish additional guarantees for the enforcement of this right.
\end{abstract}

Keywords: local government, local authorities, municipal formation, representative bodies, local deputies, city elections, right to local self-government

\section{Introduction}

For the local government to function for the benefit of people, the participation of citizens and their associations in the formation of local authorities should be ensured. Today many citizens are vague about their deputies. At best they know only the mayor's surname and local administration location (Mikheeva, 2014). In the countries that have ratified European Charter of Local Self-Government and in North American countries representative bodies play an important role in the system of local government because they are accountable to all the other local authorities. They participate in making decisions on any matters within the scope of the municipalities up to the adoption of the economic and financial base of the municipal formation.

Today Russia is particularly relevant to the search of the optimal model of legislative control of the formation of representative bodies. It is important that this model corresponds to the principle of publicity-the key principle of local government thanks to which its transparency on the local level, the accountability of local authority and its responsibility to citizens are provided. That is how European Charter of Local Self-Government ratified by Russian Federation defines the principle of publicity (Mikheev, 2014).

In this regard the experience of legal regulation of the formation of local representative bodies in the United States is of interest. The mission of our research is to identify and to compare basic common factors and distinctions of this process in the United States and Russia. We set out to define the main theoretical principals of the possibility of using the American experience in legal regime of local government in Russia, to formulate tips for improvement of the Russian legislation. The article is devoted to the scientific inquiry of ways to democratize and ensure publicity of local participation in the formation of representative government in Russia in terms of municipal American experience. The research is based on study and analysis of the regulatory sources of the United States of America and the Russian Federation, legal practice and statistical information.

\section{Methods}

Both general scientific and special methods inherent in legal science are used in the research. The dialectical method is preferred among the general scientific ones. This allows us to consider the problem of the formation of 
representative bodies through the dynamics of social processes in conjunction with various institutions of local government, practice of municipal construction. At that, the totality of social, economic and political processes that affect municipal level is taken into consideration.

Dialectical understanding of the process of formation of representative bodies implies using the systems analysis method. It is relevant when considering the institution of local representative bodies in the system of local government. The problem of representative bodies is considered in conjunction with other aspects of local government within system analysis. It is also necessary to use a synergistic method that allows us to study the possibilities of the participation of civil society in the formation of representative bodies of municipal structures. And the use of historical method is justified: it gives the opportunity to consider the formation of local government in the context of the development of local self-government authorities in Russia and the United States. A significant role is played by the method of logical analysis. Applying it, we compare the institution of formation of representative bodies of municipalities to the management of public and social systems, as well as study the mechanism of their mutual influence.

The comparative legal method plays a key role in the research. Its use is caused by comparison of legal mechanics and opportunities to exercise the rights of citizens and their associations to participate in the formation of local authorities in Russia and the United States. Thereat, the factors that affect enjoyment of this right are researched. This makes it possible for us to identify the areas in which the US experience may be considered and applied in Russia.

The sociological method is essential to the research. With the use of it we analyze American and Russian sociological studies that address the identification of various determinants (social, legal, political, cultural, historical and others) that influence the choice of model for the formation of local representative bodies. The study of the results of different opinion polls that reveal the population preferences of various municipalities of Russia and the United States in terms of the method of forming the local authorities plays a significant role as well.

The statistical method stands out among the applied scientific methods. It suggests reliance on official information. The statistical method is used when considering the structure of the deputy corps of representative bodies, the summation of local regulatory acts, the statistics of application of one or another method of public participation in the formation of representative bodies and the level of involvement in the municipal election process of various public associations.

The normative-logical method is of key importance in the research among private-scientific methods that are specific to legal science. The specific mechanisms for improving of the legislation regulating the rights of citizens and their associations to participate in the formation of the municipal representative bodies are developed by means of this method.

Taken together, these methods can achieve the stated goals and objectives of the research.

\section{Results and Discussion}

In the US the area of local government is submitted to the states' settling that can enact laws on local government. In turn, the states delegate to municipalities the part of their authority that is reflected in the local acts (Kutafin \& Fadeev, 2006). Minimization of political nature of the elections in local authorities can be considered a distinctive feature of those in the United States. Majority election system is used in the vast majority of municipalities: the candidate who outpolled the others is considered to be elected. In opposition to this, a number of Russian researchers suggest that the participation of political parties in the election process is an indicator of democracy. According to Uvarov (2006), the participation of parties in the political life can blend seamlessly with the problem solving of local government. The researcher reckons that the political nature of the local elections can provide a productive link between municipalities and state authority because in this case national political parties will alarm the state about problems and requirements of the municipal formation. In the meantime the Constitution and the Local Government Acts of almost half US states ban political parties from fielding their candidates for election of representative bodies of local authorities. Exponents of Russian academic law school, who referring to the international practices talk about the need for active involvement of political parties in the municipal election process, should pay attention to this fact.

The successful experience of democracy and local self-government accumulated over the past century in the United States largely refutes the mentioned viewpoint. This approach in the US legal system is explained by historical experience when financial and monopolistic lobby via political parties has sent their representatives to the local authorities. This led to distortion of its gist and submission of the local interests to the interests of 
public formations and business corporations. This has become possible due to lack of transparency in the process of forming candidate lists by parties. Wherefore it was decided to abandon any elements of proportional election system and move to majority in almost all states. And they did put the statutory bar on nomination of parties' candidates for deputies of the representative bodies in most states (Prudnikov, 2007).

In general, the method of city elections by the winner-take-all system does not prohibit candidates who are in the public associations and represent parties to participate in them (Kovalenko, 2014). In this case self-nomination of their candidates without participation of the party structure is possible (Medushevskii, 2014). It is not necessary for the elected local deputies who belong to a party to vote in the local representative body according to the party decision or to form any party factions. The deficiency of party factions acts to raise personal independence of each of the deputies that without doubt facilitates the realization of the principle of publicity in their work (Putnam, 1996).

One more peculiarity of the American party system that is connected with the citizens' right to take part in the formation of local authorities is the ability of the local nonpartisan private association to nominate a candidate followed by a purely formal appointment of their candidate of the relevant political party. In this case, the American political and legal traditions are based on the fact that the scale of the tasks national parties are aimed to solve is overwhelmingly global to participate in the affairs of municipalities. Therefore, American political parties and local public associations in a number of states are interested in mutual cooperation. It is manifested especially through the institution of preselection of candidates and advance poll-the primaries, which is highly influenced by local public associations. Understanding these processes parties contribute to nominating the local public associations' candidates, however without any control of their course (Adams, 2004). In turn, these associations' candidates that are elected in the majority constituencies and are not subordinate to political parties answer solely to local population in future. All of this makes both the procedure of the candidates' nomination itself and the municipal election process extremely transparent to people.

In Russia, the Constitution establishes certain guarantees of people's participation in local decision-making. Thus, Article 131 of the Constitution states that the structure of local authorities is determined independently by the population (The Constitution of the Russian Federation, 1993). Hence, the issues related to the establishment of the structure of the formation of local authorities should be solved with due consideration given to the opinion of citizens. Meanwhile, the local population stays unaware of the numerous legislative amendments in Russia that are connected with a change in the method of forming the representative bodies of the municipalities.

In general, the current state of local government in Russia is successfully characterized by S. A. Avakyan (Avakyan, 2010), according to whom the crisis in the Russian municipal formation (Avakyan, 2010) appears in the lack of actual democracy at the municipal level and in the formation of the municipal bureaucracy that is not interested in democratic development. Analyzing this situation, he points to the deficiency of the real financial base, the efficient organization of local authority and the local population belonging to these processes (Avakyan, 1994). Other authors consider exactly inoculation of truly democratic principles at the local level to be the key to the movement on the democratic path-both at the regional and national levels (Krasnov, 1992).

It is significant that under proportional election system the following electing or not electing of the particular deputy depends not only on the will of the voters, but on the decision of the higher party body authority. It is the one that decides whether to enroll or not to enroll the candidate on the voting list for the elections to the representative body. This is particularly important in the Russian electoral system, where the elections under the proportional electoral system use a system of private, but not public as in many European countries, lists. As a result, the voter is unaware of almost the entire list of candidates; he is deprived of the possibility to rank them in order of preference. This suggests that, in reality, local deputies under the proportional election system do not respond to the population but to the political parties. In this case, there is a risk of substitution of the local deputies' activities in dealing with local issues for solving political problems faced by the parties.

One of the downsides of the formation of local representative bodies under the proportional election system is the fact that citizens are deprived of the possibility of recall of a deputy. In accordance with the Federal Law "Concerning the General Principles of the Organization of Local Government in the Russian Federation", the order of the recall of a deputy of representative body by citizens does not apply to deputies elected by proportional election system. Therefore, the use of elements of proportional electoral system in the local elections not only restricts the actual responsibility of deputies to the citizens, but also places them in a position of inequality before the population of those municipalities where majority election system is applied and the voters have the opportunity of recall any of the deputies (The Federal Law "Concerning the General Principles of the Organization of Local Government in the Russian Federation", 2003). Besides, the level of transparency and 
publicity, as the basic principles of local self-government is reduced in the formation of representative bodies of municipalities by the proportional electoral system.

Meanwhile holding elections by majority system does not create optimal conditions for the enforcement of the Russian citizens' rights and for their associations taking part in the formation of representative bodies of the municipalities. After all the political parties have significant preferences here. The candidates from parties with representation in the State Duma of Russian Federation are excused from signatures collection in municipal elections (The Federal Law "Concerning the Fundamental Guarantees of the Electoral Rights and the Right to Participate in Referendum of Russian Federation Citizen"). Also, the candidates from the parties with the representation in the body of legislative power of the territorial entity of the RF and in the representative body of the municipal formation where a candidate or a party's list of candidates are going to stand in elections are excused from signatures collection in local elections by the laws of the territorial entities of the RF.

At this point it is necessary to emphasize another important aspect. In the US a candidate who is nominated in the single-seat constituency coordinates his candidacy with the party in virtue of the political tradition and for information. But in Russia, the list of candidates in majority constituencies is nominated directly by the political party in consultation with the higher party organization. Only in this case the candidates are considered to be automatically registered. However the candidates from other political parties and nonpartisan public association, the independent candidates nominated in the procedure of self-nomination require the signature collection of certain amount of voters residing in the single-member district. Thus, political parties in Russia gain an advantage of other public associations in the opportunities to participate in the formation of local governments.

Comparing the experience of Russia and the US, we come to a conclusion about the effectiveness of the majoritarian election system with typical for American model minimization of the political parties' role in the municipal election process. The efficiency and the inviolability of this system suggest the possibility of using the American experience of the formation of local representative bodies in the municipal construction in Russia considering the historical traditions, the distinctions of the legal and political culture. On this basis we believe it necessary to amend the Federal Law "Concerning the General Principles of the Organization of Local Government in the Russian Federation" and secure the election of representative bodies of municipal formations exclusively by the majoritarian system. In such case the political parties should be excluded from the number of participants of municipal election process. The legal status of the public associations as members of the municipal election process should be established in the Federal Law "Concerning the Fundamental Guarantees of the Electoral Rights and the Right to Participate in Referendum of Russian Federation Citizen". Those associations that have governing body or representative office in the territory of the municipal formation and emphasize the interest in solving local issues among the tasks in their articles should be allowed for the election in the representative bodies of municipal formations. The public associations should be released from signatures collection as an essential condition for registration of their candidates. In this case it is necessary to formalize the notification requirement for the registration whereby the public associations should be able to nominate their lists of candidates in single-seat constituencies. It is essential to entrench in the laws of territorial entities of the Russian Federation provisions according to which state regional mass media will be to provide the candidates with a platform for campaign activities in the municipal elections in the city districts and the municipal areas.

These changes in the legislation should aim at the depoliticization and the raise of openness not only of the process of the formation of local government, but of the local authority as a whole. The American experience shows that local authority is effective in the event that the activities of its agencies are accessible and understandable for the citizens, that they can directly sense the results of their work as well as have the opportunity to be turned to it. Active involvement of the nonpartisan public associations in the formation of representative bodies is able to make these processes real and the very activity of the local authorities make open and accessible to the citizens and free of the bureaucratic party procedures. In this case, the real opportunity to engage active citizens who represent the community and specialize in solving specific problems that are relevant to a particular municipal formation in the issues of local importance will appear. Eventually, this will enhance the effectiveness of the representative bodies' work and the objective settlement of local questions, but not political issues. Local youth unions, small businesses or environmental groups and other non-profit associations of citizens may be able to nominate such candidates

In the case of active participation of the public associations in the formation of representative bodies of municipalities the agenda of the matters under discussion at the municipal level may be changed considerably that will significantly raise the citizens' interest in the local elections and the institution of local government as a whole. The lack of the party factions and the deputies' responsibility before the political parties as a result of such system will create the real conditions to ensure that the principle of publicity in the local government will 
be provided both in the process of the formation, and in the future activity of the representative bodies. Under this system citizens will have an opportunity to create openly and by themselves local public associations without rigid centralized structure in order to participate in the formation of local authorities. The involvement of the public associations without legally fixed membership (social movements, social institutions, bodies of public initiative) (Federal Law "Concerning Social Associations", 1995), significantly increases the chance of the most different categories of citizens to participate in the formation of representative bodies and to convey their stands to the local authorities. As a result, it contributes to the overall strengthening of publicity in the system of local government.

\section{Conclusion}

The right of citizens and their associations to participate in the formation of the local governments is one of the main components of the citizens' right to the local self-governing. Like any other right it cannot but experience all of the trends of the state's political life. However, we must not forget that exactly through active and informed participation in all processes of forming power the citizens learn to control it and take responsibility for the choice made at the municipal level where their lives directly take place. The institution of the formation of local authority is the most important democratic institution; therefore it is important to provide the citizens and their associations with maximum opportunities to participate in the election process.

\section{Acknowledgements}

The study was funded by RHSF as a part of the research project No.14-33-01255.

\section{References}

Avakyan, S. A. (1994). Status, problems and prospects of local government in Russia. In Local government in Russia: Status, Problems and Perspectives. Matters of the Research-to-Practice Conference (p. 216). MSU. Law department.

Avakyan, S. A. (2010). Modern problems of constitutional and municipal construction in Russia. Constitutional and municipal law, 3, 5-7.

Avakyan, S. A. (2012). Democracy of protest relations: Constitutional and legal dimension. Constitutional and municipal law, 1, 2-17.

Brian, A. (2004). Public Meetings and the Democratic Process. Public Administration Review, 64(I), 273.

Federal law "Concerning Social Associations". (1995). LB, Art. 930.

Federal Law 131 "Concerning the General Principles of the Organization of Local Government in the Russian Federation" of 06.10.2003. (2003). Legislation Bulletin of the Russian Federation, 40, Art. 3822.

Federal Law 67 "Concerning the Fundamental Guarantees of the Electoral Rights and the Right to Participate in Referendum of Russian Federation Citizen" of 12.06.2002 (ed. 25.07.2011, amended 20.10.2011). (2002). Legislation Bulletin of the Russian Federation (No. 24. Art. 2253).

Kovalenko, N. E. (2008). Local Self-government as a Form of Democracy: The Study Guide (p. 243). SPb: SPbGUEF.

Krasnov, M. A. (1993). Introduction to municipal law (p. 25). Moscow.

Prudnikov, A. S. (Ed.). (2007). Local government in foreign countrie. In UNITY-DANA: Law and regulation (p. 271).

Medushevsky, A. N. (2014). Constitutional principles and ways to implement them: The Russian context: Analytical report (p. 388). Moscow, Institute of Law and Public Policy.

Mikheev, D. S. (2014). Legal analysis of European charter of the local government in the light of the principle of publicity. Life science journal, 11(6), 619-622.

Mikheeva, T. N. (2014). Novels in the legal regulation of local government. Constitutional and municipal law, 9. Putnam, R. (1996). Making the Democracy Work (pp. 65-69). Moscow: Ad Magrinem.

Uvarov, A. A. (2008). Local government and civil society. Constitutional and Municipal Law, 15, 6-9. 


\section{Copyrights}

Copyright for this article is retained by the author(s), with first publication rights granted to the journal.

This is an open-access article distributed under the terms and conditions of the Creative Commons Attribution license (http://creativecommons.org/licenses/by/3.0/). 